\title{
Checklist and Ethnobotanical Knowledge of Timber Species in Bayelsa State, Nigeria
}

\author{
Kayode $\mathrm{J}^{1}$, Ihinmikaiye $\mathrm{SO}^{2 *}$, Arowosegbe Sunday ${ }^{1}$ and Oyedeji Ayodele ${ }^{3}$ \\ ${ }^{1}$ Department of Plant Science and Biotechnology, Ekiti State University, Ado-Ekiti, Nigeria \\ ${ }^{2}$ Department of Biology, Federal University, Otuoke, Nigeria \\ ${ }^{3}$ Department of Biological Sciences, Niger Delta University, Wilberforce Island, Nigeria
}

\begin{abstract}
An appraisal of the ethnobotanical knowledge of the timber species in Bayelsa State, Nigeria, was carried out with the aid of a semi structured questionnaire guide. Five communities were selected from each of the eight Local Government Areas of the state, making a total of 40 communities used for the study. Ten respondents were randomly selected from each of the community, thus constituting 400 respondents in all, and were interviewed with the questionnaire guide. Group interviews were also conducted among the respondents to determine group consensus on the responses obtained during the individual interviews. The interviews were aimed at the determination of the timber species used in the study area, their abundance status and the ethnobotanical knowledge of the respondents on the identified timber species. The study revealed that respondents were quite familiar with the demography, ecology and physiology of the timber species in their environment irrespective of the socio-economic class they belong to. A total of 63 timber species, belonging to 28 families, were identified in the state. Field observation revealed that the choice of a species as source of timber was based majorly on the species' durability, resistance to insects (especially termites), and liability to soft rot and fungi attacks. The abundance scale used in this study revealed $13 \%$ of the identified timber species were of rare status. The indigenous knowledge of the native respondents on the identified rare species revealed that respondents were familiar with their growth forms, preferred habitats, methods of propagation and products derivable from the species. All the rare species were trees that thrive well in swamp forest of the study area and were capable of propagation from seeds. The transplantations of their wildlings were equally identified as a means of propagating them. The identified rare species have multipurpose utilities in the study area. Strategies that could conserve the rare species in the study area were proposed.
\end{abstract}

\section{Keywords}

Timber, Exploitation, Conservation, Forest, Bayelsa state

\section{Introduction}

Forest house an often complex array of resources, including woody and non-woody forest products, utilized by man. Nearly half (44\%) of the world's forest cover lies in the tropics [1], indeed, the African forest contain a wide diversity of timber species on which more than one billion people depends to varying degrees for their livelihood [2]. However, inimical exploitation of forest resources, especially timber species, obviously reduced species diversity of the tropical rainforests. Study by Franccesa, et al. [3] revealed that forests in the tropical zone are the most hardly hit and gravely threaten. Thus, the indigenous timber species inherent in the tropical forest are recurrently disappearing from the wild.

In Bayelsa State, Nigeria, the rate of timber exploitation is inappropriate. Previous study of Ihinmikaiye and Okpo [4] revealed that forest communities in the region are rich in tree species, but the distribution now skewed with respect to the intermediate class. Obute and Ekiye [5] highlighted the implications of forest fragmentation and over harvesting leading to the depletion of vegetation resource base, and consequently the loss of the knowledge about useful floral species along with their ethnobotanical applications in State. In Ndukwu and Ben-Nwadibia [6] a total of 24 species belonging to 10 different families were found to have varying applications in ethnobotany: The studies indicated that the indigenous

*Corresponding author: Ihinmikaiye Samuel Olatokunbo, Department of Biology, Federal University, Otuoke, Nigeria, ORCID iD: 0000-0001-9793-6224

Accepted: January 17, 2019

Published online: January 19, 2019

Citation: Kayode J, Ihinmikaiye SO, Sunday A, et al. (2019) Checklist and Ethnobotanical Knowledge of Timber Species in Bayelsa State, Nigeria. Insights For Res 3(1):91-98 
Citation: Kayode J, Ihinmikaiye SO, Sunday A, et al. (2019) Checklist and Ethnobotanical Knowledge of Timber Species in Bayelsa State, Nigeria. Insights For Res 3(1):91-98

people have also developed different methods for collecting, processing, using and conserving these valuable plants and/ or their products. Kayode, et al. [7] reported an increasing decline in the availability of timber species used for carving due to the annihilative method employed for harvesting the species. Many of the timber species have been over-exploited as a result of illegal logging among the indigenous people and the increasing rates of industrialization and urbanization in the State. Moreover, incessant demands by firewood seekers and woodcarvers as well as environmental pollution by crude oil pollution and pipeline vandalism have combined effects on the biodiversity and resilience of forest ecosystems of the region. Though, forests in the State still appear luxuriant because of the year- round rainfall with prevalent wetland terrain, and the fact that new leaves grow continually yet this cannot be taken to mean that the forest is still intact $[8,9]$. Recent initiative as suggested by some authors [10-12] advocate the introduction of the use of local practices, beliefs, myths and taboos into forest conservation programme. However, factors such as the presence of other tribes, new religions/westernization and poverty pose a threat to the effectiveness of such practices as a conservation tool. Thus, the present trend of timber exploitation in Bayelsa State has assumed unprecedented large scale devastation, with little thought for sustainable forest timber utilization. Kayode [13] stressed the fact that continued timber removal without the corresponding replacement within the forest is a major factor that could lead to biodiversity lost. Hence, this study aimed at assessing and documenting information about existing timber species found within the forest ecosystem of Bayelsa state, determine the ethnobotanical knowledge on them, their abundance status and suggest conservation strategies that could lead to their sustainable supply in the state.

\section{Materials and Methods}

Kayode, et al. [7] has provided the details of ecology and climate of the study area. The state was divided into three zones based on the existing political delineation as Bayelsa West (BW), Bayelsa Central (BC) and Bayelsa East (BE). Each of $B C$ and $B E$ zones is made up of three Local Government Areas (LGAs) while BW zone possessed two LGAs. Five communities were selected from each LGA, making a total of 40 communities used for the study. Ten respondents were randomly selected from each of the community, thus constituting 400 respondents in all, and were interviewed with the aid of semi structured questionnaire guide. The interviews were aimed at the determination of the timber species used in the study area, their abundance status and the ethnobotanical knowledge of the respondents on the identified timber species. Group interviews were conducted in each community in order to established group consensus on the identified species. Each group was made up of at least three respondents. Three group interviews were conducted in each village. Key informants, made up of sawmill workers, plank sellers and carpenters were identified in each zone and were also interviewed. Secondary information was also obtained from journals and books especially Hutchinson and Dalziel [14], Keay, et al. [15] and Nyananyo [16].
The similarity measures in the species identified by respondents in the different zones were determined as follow:

i. Index of Similarity (IS); as reported by Kayode [17] as:

$I S=\frac{2 c^{\prime} 100}{(a+b)}$

ii. Sorensen and Dice similarity index $\left(\mathrm{S}_{\mathrm{S}}\right)$ according to Magurran [18] as:

$$
S_{S}=\frac{2 a}{(2 a+b+c)}
$$

iii. Jaccard's index $\left(\mathrm{S}_{\mathrm{j}}\right)$; as stated by Hubalek [19] as:

$$
S_{j}=\frac{a}{(a+b+c)}
$$

iv. Kulczynski index (IK); as stated by Hubalek [19] as:

$$
I K=\frac{\frac{a}{a+b}+\frac{a}{a+c}}{2}
$$

v. Asymmetrical Similarity $\left(\mathrm{S}_{\mathrm{AS}}\right)$ as stated by Gurevitch, et al. [20] as:

$$
S_{A S}=\frac{b}{(b+2 c)}
$$

Where

$a$ is the number of timber species identified in one zone

$b$ is the number of timber species identified in another zone

$c$ is the number of identified timber species common to both zones.

The indices are useful for ecological community, they have been proposed to measure the degree to which species composition of sample sites is alike [21]. They are used here to compare similarity in the three senatorial zones in terms of their timber tree species content and or the degree to which the timber species' composition of the zones is alike base on their presence or absence in the zones. Incidence-based measures of (relative compositional) similarity are based only on the presence or absence of species. Similarity index is express in percentage, it's based on presence (not abundance) of timber tree species in compare zones, it determines how closely the timber commonly resembles in the compared zones and it exploits information on all species not only the shared species. Jaccard and Sorenson-Dice indices compare regional floral, it measure the strength of association on a zero to one (0-1) scale. Zero does not indicate association and 1 indicate maximum positive association. Kulczynski index describe the dissimilarity between the species occurring in the zones, it values range from 0 to 1 , with the value 1 taking place when the species co-occur. Asymmetry index measures the ratio of skewness to the standard error. It is an indication of the asymmetry of a distribution [22].

The relative abundance of the identified timber species was determined based on the information supplied by the respondents. Consequent on the identification of the rare species, the communities sampled were revisited and 
Citation: Kayode J, Ihinmikaiye SO, Sunday A, et al. (2019) Checklist and Ethnobotanical Knowledge of Timber Species in Bayelsa State, Nigeria. Insights For Res 3(1):91-98

Table 1: Demographic character, socio-economic status of respondents and location of the villages studied in the three senatorial districts of Bayelsa State, Nigeria.

\begin{tabular}{|c|c|c|c|c|c|}
\hline \multicolumn{2}{|l|}{ Variables } & BW & BC & BE & Average \\
\hline \multirow[t]{2}{*}{ Sex } & Male & 72 & 69 & 71 & 71 \\
\hline & Female & 28 & 31 & 29 & 29 \\
\hline \multirow[t]{3}{*}{ Age } & $<20$ & 28 & 13 & 20 & 20 \\
\hline & $20-65$ & 52 & 71 & 65 & 63 \\
\hline & $>65$ & 20 & 16 & 15 & 17 \\
\hline \multirow[t]{3}{*}{ Religion } & Christian & 82 & 88 & 88 & 86 \\
\hline & Moslem & - & - & - & - \\
\hline & Others & 18 & 12 & 12 & 14 \\
\hline \multirow[t]{2}{*}{ Literacy Status } & Literate & 64 & 63 & 65 & 64 \\
\hline & Illiterate & 36 & 37 & 35 & 36 \\
\hline \multirow[t]{3}{*}{ Economic Status } & Low & 66 & 68 & 77 & 70 \\
\hline & Medium & 30 & 32 & 19 & 27 \\
\hline & High & 4 & - & 4 & 1 \\
\hline \multirow[t]{2}{*}{ Occupation } & Farming & 94 & 79 & 88 & 87 \\
\hline & Non-Farming & 6 & 21 & 12 & 13 \\
\hline
\end{tabular}

five respondents were selected in each community. The Indigenous Knowledge (IK) of the selected respondents on the identified rare species was determined and used to propose conservation strategies the species in the study area.

Visits were also conducted to forest reserves in the State and the extent of anthropogenic disturbances in each reserve were observed and recorded.

\section{Results}

The demographic and socioeconomic status of respondents was shown in Table $1.71 \%$ of the respondents were males, of between the ages of $20-65$ years (63\%), Christian $(88 \%)$, literates (64\%) farmers (86.9\%) and mostly of low economic status. Field observation revealed that they were conversant with the timber species in their environment. A total of 63 timber species belonging to 28 families were identified in the three senatorial zones of the State (Table 2). 59, 54 and 58 timber species were identified in $\mathrm{BC}, \mathrm{BE}$ and $\mathrm{BW}$ respectively.

Table 2: Botanicals used for timber among the major ethnic groups in Bayelsa State.

\begin{tabular}{|c|c|c|c|c|c|}
\hline$S / N$ & Botanical names & Families & Local names & $\begin{array}{l}\text { Availability } \\
\text { status }\end{array}$ & Indigenous Knowledge \\
\hline 1 & Alstonia congensis & Rubiaceae & Kigbe & Rare & Soft and light \\
\hline 2 & Alstonia macrophylla & Apocynaceae & Obori & Rare & $\begin{array}{l}\text { It's of superior quality, less liable to attack by } \\
\text { insects }\end{array}$ \\
\hline 3 & Anopyxis klaineana & Rhizophoraceae & Beni-tobutobu & Abundant & Hard, resist termite attack \\
\hline 4 & $\begin{array}{l}\text { Anthocleista } \\
\text { djalonensis }\end{array}$ & Pandaceae & $\begin{array}{l}\text { Sokoroko, } \\
\text { Osunwa }\end{array}$ & Very Abundant & $\begin{array}{l}\text { Availability, is a strong wood, termites proof \& } \\
\text { durable }\end{array}$ \\
\hline 5 & Anthocleista vogelii & Pandaceae & Osunwa & Very. Abundant & Medium hard, keep well \\
\hline 6 & Antiaris toxica & Moraceae & Alalawa & Abundant & Hard, availability \\
\hline 7 & Astonia bononei & Apocynaceae & Kigbo & Abundant & $\begin{array}{l}\text { Soft, easy to saw, good for light furniture and } \\
\text { carpentry work }\end{array}$ \\
\hline 8 & Aubrevillea platycarpa & Mimosaceae & Piri agbaka & Frequent & Hard, durable, soft rot resistance \\
\hline 9 & Avicennia germinans & Acanthaceae & Ekeu & Abundant & Hard, durable \\
\hline 10 & Brachystegia nigerica & Caesalpiniaceae & Okolodo & Occasional & Resist soft rot and decay \\
\hline 11 & Ceiba pentandra & Bombacaceae & Talar & Frequent & Light weight easy to work, resist decay \\
\hline 12 & $\begin{array}{l}\text { Combretodendron } \\
\text { macrocarpum }\end{array}$ & Lecythidaceae & Ozen & Rare & Fairly hard, durable \\
\hline 13 & $\begin{array}{l}\text { Ctenolophon } \\
\text { englerianus }\end{array}$ & Ctenolophonaceae & Yowei tin & Abundant & Hard, durable, resist dry borer \\
\hline 14 & Dennetia tripetela & Annonaceae & Piri tin & Abundant & Soft, good for casual woodwork \\
\hline 15 & $\begin{array}{l}\text { Entandrophragma } \\
\text { cylindricum }\end{array}$ & Meliaceae & Aboudikor & Rare & Medium hard, keep well \\
\hline 16 & $\begin{array}{l}\text { Entandrophragma } \\
\text { excelsum }\end{array}$ & Meliaceae & Ohor & Occasional & Heavy, durable \\
\hline 17 & Erythrina senegalensis & Papilionaceae & Ogbolo Ibolo & Abundant & Hard, durable \\
\hline 18 & Erythrophleum ivorense & Caesalpiniaceae & Eren & Frequent & Hard, resist decay, fungi and termite attack \\
\hline 19 & $\begin{array}{l}\text { Erythrophleum } \\
\text { suaveolens }\end{array}$ & Caesalpiniaceae & Eren & Frequent & Durable \\
\hline 20 & Funtumia elastica & Apocynaceae & $\begin{array}{l}\text { Orobatin, Silk } \\
\text { rubber }\end{array}$ & Frequent & Soft, easy to work on. \\
\hline 21 & Garcinia kola & Clusiaceae & Okan & Abundant & $\begin{array}{l}\text { Fairly strong, termites proof, good for } \\
\text { carpentry }\end{array}$ \\
\hline 22 & Gmelina arborea & Verbenaceae & Epele & Abundant & Light weight, hard and durable \\
\hline 23 & $\begin{array}{l}\text { Gossampinus } \\
\text { angulicarpa }\end{array}$ & Bombacaceae & Esisagha, Sikaka & Frequent & Hard, resist rot \& decay, termites proof \\
\hline 24 & Hevea brasiliensis & Euphorbiaceae & Roba tin & Abundant & Availability, use for casual work \\
\hline
\end{tabular}


Citation: Kayode J, Ihinmikaiye SO, Sunday A, et al. (2019) Checklist and Ethnobotanical Knowledge of Timber Species in Bayelsa State, Nigeria. Insights For Res 3(1):91-98

\begin{tabular}{|c|c|c|c|c|c|}
\hline 25 & Irvingia gabonensis & Irvingiaceae & Okpukpa & Very abundant & $\begin{array}{l}\text { Availability, durability, strong wood with good } \\
\text { working qualities }\end{array}$ \\
\hline 26 & Irvingia smithii & Irvingiaceae & Bakalaza tin & Abundant & Workable \\
\hline 27 & Khaya anthotheca & Meliaceae & Ipelemu & Frequent & $\begin{array}{l}\text { Highly valued for furniture \& carpentry, with } \\
\text { good qualities, termites proof, easy to work on }\end{array}$ \\
\hline 28 & Khaya ivorensis & Meliaceae & Digi tin, Kow & Frequent & Soft, easy to work on. Durable \\
\hline 29 & Klaindoxa gabonensis & Ixonanthaceae & Akoo & Abundant & Strong, durable, termite proof \\
\hline 30 & Laguncularia racemosa & Combretaceae & Orke & Very abundant & Moderately hard and heavy \\
\hline 31 & Lophira alata & Ochnaceae & Kuru & Abundant & Hard, suitable for furniture \\
\hline 32 & Mammae Africana & Guttiferaceae & Bolo tin & Occasional & Hard, termite proof and durable \\
\hline 33 & Mansonia altissima & Malvaceae & Ozon & Rare & $\begin{array}{l}\text { Light weight, yield attractive plywood, easy to } \\
\text { work on and durable }\end{array}$ \\
\hline 34 & Milicia excels & Moraceae & $\begin{array}{l}\text { Alagbatin, } \\
\text { Olokpata }\end{array}$ & Rare & Hard, yield plank wood, resist insects attack \\
\hline 35 & Mitragyna stipulosa & Naucleaceae & Bau & Occasional & Hard, workable, durable \\
\hline 36 & Monodora myristica & Annonaceae & Okogolo & Abundant & $\begin{array}{l}\text { Hard, Easy to work, insects' resistant. Suitable } \\
\text { for carpentry }\end{array}$ \\
\hline 37 & Musanga cecropioides & Urticaceae & Obonya tin & Very abundant & Soft, easy to work on \\
\hline 38 & Nauclea diderrichii & Rubiaceae & Owoso & Occasional & $\begin{array}{l}\text { Strong, durable, resist insects attack, respond } \\
\text { well to sawing operations }\end{array}$ \\
\hline 39 & $\begin{array}{l}\text { Nesogordonia } \\
\text { papaverifera }\end{array}$ & Malvaceae & Ikpalata & Abundant & $\begin{array}{l}\text { Hard, easy to work on, durable, accept nail and } \\
\text { screw easily }\end{array}$ \\
\hline 40 & Pachystela brevipes & Melastomataceae & Ayanya, Adayan & Abundant & Strong, resist rot and decay \\
\hline 41 & Panda oleosa & Pandaceae & Obiritia & Abundant & Availability easy to saw and work on \\
\hline 42 & Pentadesma butyracea & Clusiaceae & Akanti & Frequent & Heavy, resist termites attack. Durable \\
\hline 43 & $\begin{array}{l}\text { Piptadeniastrum } \\
\text { africanum }\end{array}$ & Mimosaceae & Sanga & Occasional & $\begin{array}{l}\text { Hard, resistance to fungi and insects. Easy to } \\
\text { work on }\end{array}$ \\
\hline 44 & Prioria mannii & Caesalpiniaceae & Itofiya & Abundant & Resist dry wood borer, fungi and termite \\
\hline 45 & Pterocarpus mildbraedii & Papilionaceae & geneghar & Abundant & Hard resistant to insect, easy to work on \\
\hline 46 & Pycnanthus angolensis & Myristicaceae & Abbo & Abundant & Soft, availability, easy to work on \\
\hline 47 & Rhizophora harrisonii & Rhizophoraceae & Angala & Very abundant & Strong, attractive as plank \\
\hline 48 & $\begin{array}{l}\text { Ricinodendron } \\
\text { heudelotii }\end{array}$ & Euphorbiaceae & Eke & Frequent & Light, soft, easy to work on \\
\hline 49 & Sacoglottis gabonensis & Houmiriaceae & Tala & Abundant & Soft, easy to work on \\
\hline 50 & Scottellia klaineana & Achariaceae & Ewonoh & Rare & Fairly hard, susceptible to fungi attack \\
\hline 51 & Symphonia globulifera & Clusiaceae & Akololo & Abundant & $\begin{array}{l}\text { Ideal for fine furniture work, strong, durable, } \\
\text { rot resistant easy to work on }\end{array}$ \\
\hline 52 & Terminalia acuminate & Combretaceae & $\begin{array}{l}\text { Oweibalaa, } \\
\text { abalaa }\end{array}$ & Abundant & It yield good plank, strong \& easy to work on \\
\hline 53 & Terminalia ivorensis & Combretaceae & $\begin{array}{l}\text { Turubainmo, } \\
\text { ambe, sebe tin }\end{array}$ & Frequent & Workable, easy to saw, good for furniture work \\
\hline 54 & Treculia Africana & Moraceae & Oyen, okorien & Very abundant & $\begin{array}{l}\text { Availability, suitable for furniture making, } \\
\text { durable }\end{array}$ \\
\hline 55 & Triplochiton scleroxylon & Sterculiaceae & Phar & Rare & Hard, light weight, attractive durable \\
\hline 56 & Uapaca guineensis & Uapacaceae & Ilee & Abundant & Hard and durable \\
\hline 57 & Uapaca heudelotii & Uapacaceae & Iyoro ile & Abundant & Fairly hard, resist termites and insects attack \\
\hline 58 & Uapaca staudtii & Uapacaceae & Okuruba ile & Abundant & Termite proof, durable \\
\hline 59 & Vitex doniana & Verbenaceae & Moron & Abundant & Strong, durable, easy to work on \\
\hline 60 & Vitex grandifolia & Verbenaceae & Buran-furu & Abundant & Resist termite attack \\
\hline
\end{tabular}

Field observation revealed that the choice of a species as source of timber was based majorly on the species' durability, resistance to insects (especially termites), and liability to soft rot and fungi attacks. Table 3 revealed that the species identified in the different zones were quite similar to one another. The similarities can be expressed as:

\section{$\mathrm{BW}-\mathrm{BC}>\mathrm{BE}-\mathrm{BC}>\mathrm{BE}-\mathrm{BC}$}

The abundance scale used in this study revealed that $12 \%$, $47 \%, 18 \%, 10 \%$ and $13 \%$ of the identified timber species were of very abundant, abundant, frequent, occasional and rare status respectively. The indigenous knowledge of the native respondents on the identified rare species revealed that 
Citation: Kayode J, Ihinmikaiye SO, Sunday A, et al. (2019) Checklist and Ethnobotanical Knowledge of Timber Species in Bayelsa State, Nigeria. Insights For Res 3(1):91-98

Table 3: Similarity measures on the occurrence of timber species in the three zones of the study area.

\begin{tabular}{|l|l|l|l|l|l|}
\hline \multirow{2}{*}{ Zones } & \multicolumn{5}{|l|}{ Indices of Similarity } \\
\cline { 2 - 6 } & IS & S $_{\text {J }}$ & S $_{\text {SD }}$ & S $_{\text {o }}$ & S $_{\text {AS }}$ \\
\hline BW-BE & 89.1 & 0.3 & 0.5 & 2.5 & 0.3 \\
\hline BW-BC & 95.7 & 0.3 & 0.5 & 2.6 & 0.3 \\
\hline BE-BC & 91.9 & 0.3 & 0.5 & 2.5 & 0.3 \\
\hline
\end{tabular}

*Size according to secondary information. respondents were familiar with their growth forms, preferred habitats, methods of propagation and products derivable from the species (Table 4). All the rare species were trees that thrive well in swamp forest and capable of propagation from seeds. The transplantations of their wildlings were equally identified as a means of propagating these species. All the identified rare species have multipurpose utilities in the study area. Thus, apart from their use as timber, they were also

Table 4: Conservation inference of the respondents' indigenous knowledge on the rare species.

\begin{tabular}{|c|c|c|c|c|}
\hline$S / n$ & Feature & Identified Rare Species & $\begin{array}{l}\text { Respondents' Indigenous } \\
\text { Knowledge }\end{array}$ & Conservation Inference \\
\hline 1 & Growth Form & $\begin{array}{l}\text { Alstonia congensis } \\
\text { Alstonia macrophylla } \\
\text { Combretodendron } \\
\text { macrocarpum } \\
\text { Entandrophragma } \\
\text { cylindricum } \\
\text { Mansonia altissima } \\
\text { Milicia excelsa } \\
\text { Scottellia klaineana } \\
\text { Triplochiton scleroxylon }\end{array}$ & $\begin{array}{l}\text { Tree } \\
\text { Tree } \\
\text { Tree } \\
\\
\text { Tree } \\
\text { Tree } \\
\text { Tree } \\
\text { Tree } \\
\text { Tree }\end{array}$ & $\begin{array}{l}\text { Respondents are quite familiar with } \\
\text { trees hence an enlightenment campaign } \\
\text { on the importance of trees that } \\
\text { necessitates tree cultivation by the } \\
\text { aboriginals is required. }\end{array}$ \\
\hline 2 & Habitat & $\begin{array}{l}\text { Alstonia congensis } \\
\text { Alstonia macrophylla } \\
\text { Combretodendron } \\
\text { macrocarpum } \\
\text { Entandrophragma } \\
\text { cylindricum } \\
\text { Mansonia altissima } \\
\text { Milicia excelsa } \\
\text { Scottellia klaineana } \\
\text { Triplochiton scleroxylon }\end{array}$ & $\begin{array}{l}\text { Rainforest, Swamp forest } \\
\text { Rainforest, Swamp forest } \\
\text { Rainforest, Savannah } \\
\text { Swamp forest, Rainforest } \\
\text { Rainforest, Savannah } \\
\text { Forest Island, Rainforest, Derived } \\
\text { savannah } \\
\text { Swamp forest, Rainforest } \\
\text { Rainforest }\end{array}$ & $\begin{array}{l}\text { The swamp forest vegetation of the } \\
\text { study area will support the cultivation of } \\
\text { most of the rare species. }\end{array}$ \\
\hline 3 & Propagation & $\begin{array}{l}\text { Alstonia congensis } \\
\text { Alstonia macrophylla } \\
\text { Combretodendron } \\
\text { macrocarpum } \\
\text { Entandrophragma } \\
\text { cylindricum } \\
\text { Mansonia altissima } \\
\text { Milicia excelsa } \\
\text { Scottellia klaineana } \\
\text { Triplochiton scleroxylon }\end{array}$ & $\begin{array}{l}\text { Seeds, Wildlings } \\
\text { Seeds, Wildlings } \\
\text { Seeds, Wildlings } \\
\text { Seeds, Wildlings } \\
\text { Seeds, Wildlings } \\
\text { Seeds, Wildlings } \\
\text { Seeds, Wildlings } \\
\text { Seeds, Wildlings }\end{array}$ & $\begin{array}{l}\text { (a) Respondents could be encourage to } \\
\text { preserve wildlings of these species in } \\
\text { their farms. } \\
\text { (b) The aborigines' familiarity with seeds } \\
\text { propagation could be exploited through } \\
\text { provision of seeds and/or seedlings of } \\
\text { these species for cultivation in the study } \\
\text { area. }\end{array}$ \\
\hline 4 & Major Products & $\begin{array}{l}\text { Alstonia congensis } \\
\text { Alstonia macrophylla } \\
\text { Combretodendron } \\
\text { macrocarpum } \\
\text { Entandrophragma } \\
\text { cylindricum } \\
\text { Mansonia altissima } \\
\text { Milicia excelsa } \\
\text { Scottellia klaineana } \\
\text { Triplochiton scleroxylon }\end{array}$ & $\begin{array}{l}\text { Timber, Medicine, Shade } \\
\text { Timber, Furniture } \\
\text { Timber, Medicine, Fuel } \\
\text { Timber, Medicine } \\
\text { Timber, Medicine } \\
\text { Timber, Medicine, Shade } \\
\text { Timber, Medicine } \\
\text { Timber, Medicine, Foods }\end{array}$ & $\begin{array}{l}\text { Investment in these species will meet } \\
\text { future needs of respondents and } \\
\text { provide worthwhile economic returns. }\end{array}$ \\
\hline
\end{tabular}


Citation: Kayode J, Ihinmikaiye SO, Sunday A, et al. (2019) Checklist and Ethnobotanical Knowledge of Timber Species in Bayelsa State, Nigeria. Insights For Res 3(1):91-98

Table 5: Forest reserves in Bayelsa state, Nigeria.

\begin{tabular}{|l|l|l|l|l|}
\hline $\mathbf{S} / \mathbf{n}$ & Reserve & Size & Main LGA & Observed Anthropogenic factors \\
\hline 1. & Apoi Creek Forest Reserve & $64.77 \mathrm{~km}^{\mathbf{2}}$ & Southern ljaw & H, L, OE \\
\hline 2. & Bayelsa National Forest & NA & Yenagoa & H, L \\
\hline 3. & Edumanon Forest Reserve & $86.76 \mathrm{~km}^{2}$ & Ogbia, Nnebe & H, L, OE, PD \\
\hline 4. & Egbedi Creek Forest Reserve & $66.32 \mathrm{~km}^{2}$ & Kolokuma/Opokuma & $\mathrm{H}, \mathrm{L}$ \\
\hline 5. & Ikibiri Creek Forest Reserve & $191.71 \mathrm{~km}^{2}$ & Southern ljaw & $\mathrm{H}, \mathrm{L}, \mathrm{F}$ \\
\hline 6. & Nun River Forest Reserve & $97.15 \mathrm{~km}^{2}$ & Southern ljaw, Yenagoa & H, L, F \\
\hline 7. & Taylor Creek Forest Reserve & $218.91 \mathrm{~km}^{2}$ & Yenagoa & H, L \\
\hline
\end{tabular}

NA: Not Available; ${ }^{* *}$ The main location(s) (LGA), where the forest is domicile; ${ }^{+} \mathrm{H}$ : Hunting; L: Logging, OE: Oil Exploration; F: Farming; PD: Plantation Development.

used for medicine. Table 5 revealed that five forest reserves abound in the study area. These reserves were heavily preyed upon by anthropogenic factors especially hunting, logging, oil exploration and farming activities. Field observation revealed that while the Niger Delta University is located at the fringing forest of Nun River Forest Reserve, an expansion of $E$. guineensis plantation was on-going in Edumanon Forest Reserve hence these reserves are diminishing rapidly. Similarly, oil exploration pipelines were observed at Apoi Creek and Edumanon Forest Reserves. Thus, the populations of an array of trees in the reserves are being threatened.

\section{Discussion}

The indigenous community of the study area maintained verse knowledge on the utility values of plant species in their environment. The awareness demonstrated on timber species cut across the socio-economic strata thus affirming the previous contention of Kayode [23] that socio-economic classifications were not prerequisites to tree mindedness of the indigenous people. The indigenous people derived numerous products from the forest in their environment. Inyang [24] asserted that the entire Niger Delta region of Nigeria is richly blessed with a variety of natural resources, especially forest resources of immense economic potentials. A total of 63 indigenous timber species, belonging to 28 families were identified in this study. This figure fall within that of Gill and Okoegwale [25] who documented 74 timber species as number of indigenous timber in Nigeria, The indigenous knowledge of the respondents on the identified species included their texture, durability and susceptibility to fungi and pests. Thus, the desirable characters that a species possessed were used to determine its suitability for a particular wood product. This observation tends to support the previous assertion of Bloniarz [26] that the intended utility dictates the timber species to be used. Researchers such as Kayode [13], Adekunle, et al. [27] and Adekunle, et al. [28] have shown that people always prefer to use species that are of superior quality and high economic value. The various similarity indices used in this study tend to suggest similarities in the diversity of the identified species in the tree different zones of the study area. Cantlon [29] contended that areas with similar microclimate will support the same type of plant species. The respondents also demonstrated considerable knowledge on the ecology and physiology of the identified species. Gadgil, et al. [30] asserted that Indigenous peoples with a historical continuity of resource-use practices often possess a broad knowledge base of the behavior of complex ecological systems in their own localities. They contended further that this knowledge has accumulated through a long series of observations transmitted from generation to generation. The respondents in this study were equally versed in the demography of the identified timber species. Those that were rare in occurrence were identified and the rare species were found to be trees capable of being cultivated in the study area. Thus, the application of the knowledge-practicebelief complex of indigenous peoples relating to conservation of biodiversity, as previously advocated by Gadgil, et al. [30] becomes relevant. The indigenes of the study area were quite familiar with trees and with propagation from seeds. Thus, an awareness campaign on the need to plant indigenous tree species might likely produce a promising result. Similarly, preservation of tree wildlings of the identified species could be encouraged. The identified species have multiple utilities in the study area. This might constitutes a veritable incentive to their cultivation by the indigenous community.

The existing forest reserves were presently prone to deforestation through hunting, logging, oil exporation and plantation development and farming. Hunting was prominent in the study area to the extent that a wildlife market abounds in Yenagoa, the state capital. The market-Swali Marketis situated in close proximity to five of the existing forest reserve. The trade in wildlife breeds poaching while the reckless use of firearms in these forest reserves hindered forest policing activities by forest guards. Akani, et al. [31] observed that the thriving wildlife market in Swali Market could be attributed not only to its closeness to the reserves but also its accessibility by good roads and water. The market is located on the shore of the River Nun. Similarly, Hamadina, et al. [32] asserted that the ongoing and future development project at the campus of the Niger Delta University shall have significant adverse impacts on the Nun River Forest Reserve directly through habitat loss/fragmentation, nuisance, influx of people; and indirectly by exacerbating the existing threats. At present logging activities are being carried out indiscriminately and mostly illegal in all these reserves. The reserves in the study area are further damaged by plantation establishment such as the expansion of oil palm plantations in Edumanom Forest Reserve, the oil pollution arising from the oil exploration activities. Oil pollution cause depletion of oxygen, reduce plant growth [33], increased defoliation and yellowed leaf colour in mangrove [34]. Mangroves are now known to be slow growing and take decades to be replaced by mature vegetation. Hoff [35] revealed that mangrove does 
Citation: Kayode J, Ihinmikaiye SO, Sunday A, et al. (2019) Checklist and Ethnobotanical Knowledge of Timber Species in Bayelsa State, Nigeria. Insights For Res 3(1):91-98

not recover quickly from oil pollution.

In conclusion, this study revealed that respondents were aware of the continuous erosion of timber species in the study area thus confirming the previous observation of LENF [36]. Preference for timber species is presently skewed toward the species that were available rather than the choice species thus lending credence to a similar observation made by Kayode [13]. Consequent on this observation the need to halt the present trend of deforestation in the study area is inevitable. Government should embark on community based forest management scheme. The existing laws on forest management are obsolete; they should be reviewed and made more effective. Also, personnel of forestry department should be well-equipped and mobilized for efficient and effective forest monitoring. Pollution, mostly arising from oil bunkering activities should be controlled. Public awareness campaigns should be embarked with a view to enumerating the dangers involved in the genetic loss of the indigenous timber species. Perhaps some of the existing forest formations in the state should be dedicated to sprits and deities. LENF [36] previously asserted that the native laws have been successful in preserving these 'evil forests'. Studies have shown that people respect the traditional laws and obey traditional rules and regulations. The use of such ancient conservation rules and practices has been used effectively elsewhere in some climes [37].

\section{Authors' Contribution}

S. O. Ihinmikaiye and J. Kayode carried out the field enthobotany research and draft the manuscript. $S$. Arowosegbe participated in the study inception, contributed to the draft of the manuscript. A. A. Oyedeji participated in the field research and helped to confirm the timber species determination. All authors read and approved the final manuscript.

\section{References}

1. Keenan RJ, Reams GA, Achard F, et al. (2015) Dynamics of global forest area: Results from the FAO Global Forest Resources Assessment 2015. Forest Ecology and Management 352: 9-20.

2. World Bank (2011) Wood-based biomass energy development for Sub-Saharan Africa-Issues and approaches. Africa Renewable Energy Access Program (AFREA).

3. Franccesa G, Claudia C, Manuela G (2009) Biodiversity conservation and habitat management: An overview. Encyclopedia of Life Support Systems (EOLSS).

4. Ihinmikaiye SO, Unanaonwi OE (2018) Tree species structure and diversity in the lowland - rain forest zone of Bayelsa State. J Ecol \& Nat Resour 2: 126.

5. Obute GC, Ekiye E (2008) Ethnobotanical applications of some Floral Species in Bayelsa State, Nigeria. Ethnobotanical Leaflets 12: 713-718.

6. Ndukwu BC, Ben Nwadibia NB (2003) Studies on ethnomedicinal applications of condiments and spices in the Niger delta area of Nigeria. Ethnobotanical Leaflets.

7. Kayode J, Ihinmikaiye SO, Arowosegbe S, et al. (2016) Conservation of botanicals used for carving by the ljaw ethnic group of Bayelsa State Nigeria. International Journal of Natural Resource Ecology and Management 1: 58-62.

8. Adekunle VAJ, Olagoke AO, Ogundare LF (2013) Timber exploitation rate in tropical rainforest ecosystem of southwest Nigeria and its implications on sustainable forest management. Applied Ecology and Environmental Research 11: 123-136.

9. Agbo FU, Onyenekwe SC, Obasi FA (2015) Sustainable timber utilization and management in Ebonyi State, Nigeria. African Journal of Agricultural Research 10: 2061-2067.

10. Jimoh SO, Ikyaagba ET, Alarape AA, et al. (2012) The role of traditional laws and taboos in wildlife conservation in the Oban Hill sector of Cross River National Park (CRNP), Nigeria. J Hum Ecol 39: 209-219.

11. Rim-Rukeh A, Irerhievwie G, Agbozu IE (2013) Traditional beliefs and conservation of natural resources: Evidences from selected communities in Delta State, Nigeria. International Journal of Biodiversity and Conservation 5: 426-432.

12. Kayode J, Ihimikaiye SO, Oyedeji AA (2015) The Potentials of Myths and Taboos in forest conservation: Could they serve as benign strategies in Bayelsa State of Nigeria? Journal of Global Agriculture and Ecology 5: 1-6, 2454-4205.

13. Kayode J (2007) Conservation implications of timber supply pattern in Ekiti State, Nigeria. Research Journal of Forestry 1: 86-90.

14. Hutchinson J, Dalziel JM (2014) Flora of West Tropical Africa. Internet Archive, San Francisco, CA.

15. Keay RWJ, Onochie CFA, Stanfield DP (1964) Nigerian trees. Department of Forest Research, Ibadan, Volume 1 and 2.

16. Nyananyo BL (2006) Plants from the Niger Delta. Onyoma Research Publications, Port Harcourt, Nigeria.

17. Kayode J (1999) Phytosociological investigation of compositae weeds in abandoned farmlands in Ekiti State, Nigeria. Compositae Newsletter 34: 62-68.

18. Magurran A (2004) Measuring biological diversity. Blackwell Publishing, Oxford, UK.

19. Hubalek Z (1982) Coefficients of association and similarity, based on binary (presence-absence) data: An evaluation. Biological Reviews of the Cambridge Philosophical Society 57: 669-689.

20. Gurevitch J, Scheiner SM, Fox GA (2002) The ecology of plants. Sinauer Associates Inc., Massachusetts, USA.

21. Kallio A, Puolamaki K, Fortelius M, et al. (2010) Correlations and Co-occurrences of taxa: The role of temporal, geographic, and taxonomic restrictions. Society for vertebrate Paleontology.

22. (2018) Similarity measures.

23. Kayode J (2005) Conservation perception of endangered tree species by rural dwellers of Ekiti State, Nigeria. Journal of Sustainable Forestry 19: 1-9.

24. Inyang S (2009) Nigeria: South South - The anatomy of a people, resources. Vanguard Newspaper.

25. Gill LS, Okoegwale EE (1991) Nigeria Timber 1: Their physical properties and possible end-uses. Wood News 1: 39-41.

26. Bloniarz DV (1992) Street trees, overhead utlitly distribution, and physical infrastructure: Design implictions, maintenance costs and proposed alternatives. Northeast Center for Urban \& Community Forestry USDA Forest Service, Amherst, MA, 151.

27. Adekunle VAJ, Akindele SO, Fuwape JA (2008) Diversity and 
Citation: Kayode J, Ihinmikaiye SO, Sunday A, et al. (2019) Checklist and Ethnobotanical Knowledge of Timber Species in Bayelsa State, Nigeria. Insights For Res 3(1):91-98

bio-volume of tree species in natural forest ecosystem in the bitumen-producing area of Ondo State, Nigeria: A baseline study. Biodiversity and Conservation 17: 2735-2755.

28. Adekunle VAJ, Olagoke AO, Ogundare LF (2010) Rate of timber production in a tropical rainforest ecosystem of southwest Nigeria and its implications on sustainable forest management. Journal of Forestry Research 21: 225-230.

29. Cantlon JE (1953) Vegetation and microclimates on North and South slopes of Cushetunk Mountain, New Jersey. Ecological Monographs 23: 241-270.

30. Gadgil M, Berkes F, Folke C (1993) Indigenous knowledge for biodiversity conservation. Ambio 22: 151-156.

31. Akani GC, Amadi N, Eniang EA, et al. (2015) Are mammal communities occurring at a regional scale reliably represented in "hub" bushmeat markets? A case study with Bayelsa State (Niger Delta, Nigeria). Folia Zoologica 64: 79-86.

32. Hamadina M, Otobotekere D, Anyanwu D (2007) Impact assessment and biodiversity considerations in Nigeria: A case study of Niger Delta University campus project on wildlife in Nun
River Forest Reserve. Management of Environmental Quality 18: 179-197.

33. Enujiugha VN, Nwanna LC (2004) Aquatic oil pollution impact indicators. Journal of Applied Sciences and Environmental Management 8: 71-75.

34. Burns KA, Garrity SD, Levings SD (1993) How many years until mangrove ecosystems recover from catastrophic oil spills? Marine Pollution Bulletin 26: 239-248.

35. Hoff R (2010) Oil spills in mangroves. Planning and response considerations. National Oceanic and Atmospheric Administration US Department of Commerce, USA.

36. LENF (1998) Living Earth Environment Action Programme; Participatory learning and action report unpublished report. Living Earth Nigeria Foundation, Port Harcourt, Nigeria.

37. ND-HERO (2006) Institutional structure, Policies and Legal framework. In: Ezealor A, Akinsola $O$, The renewable natural resources of the Niger Delta; Options for its sustainable management. Macarthur Foundation USA / NCF Lagos, 32-42. 